\title{
Special Education Management and Formalism in Inclusive Public Policies: The Case of Brazil
}

\author{
Bruno Luiz Américo ${ }^{1}$, Fagner Carniel $^{2}$ \& Adriana Roseli Wünsh Takahashi ${ }^{1}$ \\ ${ }^{1}$ School of Management, Universidade Federal do Paraná, Curitiba, Brazil \\ ${ }^{2}$ Political Sociology, Universidade Federal de Santa Catariana, Florianópolis, Brasil \\ Correspondence: Adriana Roseli Wünsch Takahashi, School of Management, Universidade Federal do Paraná, \\ Av. Pref. Lothário Meissner, 632, Sala SA 02w.11, Curitiba-PR, Brazil, 80210-170. Tel: 55-41-3-360-4365. \\ E-mail: adrianarwt@terra.com.br
}

Received: May 8, 2012 Accepted: May 23, 2012 Online Published: October 18, 2012

doi:10.5539/par.v1n1p72 URL: http://dx.doi.org/10.5539/par.v1n1p72

\begin{abstract}
The idea of inclusive education has gained prominence in the ideological context of modern Western democracies. Thus, this analysis focuses on the understanding of how the Brazilian inclusive education has been managed from the Decree-Law $n^{\circ}$ 6.571/2008, which was repealed on November 17, 2011, considering the formalism perspective. Formalism is taken as a perspective of analysis of the inclusive public policies, which allows us to question the apparent stability and uniformity of institutional practices and discourse of the national administration. The work's approach is largely qualitative, and uses multiple methods. Two steps were taken, starting with all the Brazilian State Boards of Education (survey research), and concluding with the Rio Grande do Norte State Board of Education and one of its school (case study). Data was collected through documental research and interviews with key actors, and analyzed by content analysis. It was found that, despite the legal pressure on the environment to an isomorphism of practices among State Boards, there are peculiarities among them, justified by the contextual and cultural aspects that are shared by actors and organizations. In the specific case study of the Rio Grande do Norte State Board of Education, it was concluded that the formalistic practice allows questioning the effectiveness of the official knowledge policies and its other form of narrative that regards not only the special education, but the very plurality of logical and social experiences. From a theoretical point of view, the study has called attention to the presence of formalism in special education administration.
\end{abstract}

Keywords: special education management, inclusive public policy, formalism

\section{Introduction}

According to the "IBGE'S 2000 Census, Brazil has 24.5 million people with disabilities, which equals $14.5 \%$ of the country's population. From these, $48.1 \%$ were declared visually impaired, $22.9 \%$ with motor disability, $16.7 \%$ with hearing impairments, $8.3 \%$ with mental retardation and $4.1 \%$ with physical disabilities" (APAE Brazil, 2011).

Several authors highlight that the idea of an inclusive education has gained prominence in the ideological context of modern Western democracies (Pinheiro, 2003, Oliveira, 2009). Politically articulated by numerous international bodies and often presented as a "new" educational paradigm, this perspective has been incorporated by many nations through different agents: conferences, official meetings, methodologies, pilot projects, manuals, among others (Note 1).

Motivated by these political ideas that were hegemonic consolidated in the late twentieth century, Brazil, through the Ministry of Education (MEC), promulgated the Decree $\mathrm{n}^{\circ} 6.571 / 2008$, providing that all schools must enroll the whole number of students with special needs in a regular class. The aforementioned decree was repealed by the Brazilian president Dilma Rousself on November 17, 2011, by the Decree $\mathrm{n}^{\circ}$ 7.611-11. During approximately four years, the Brazilian education system found itself influenced to respond demands (not only international anymore) for restructuring the organization of special education (public and private) of its federal units (Note 2).

The scope of Brazilian studies that deal with educational management to examine how international agreements and legal documents, which followed the Universal Declaration of Human Rights (1948), show signs of power 
that foreign agencies have to interfere with national and local realities throughout the West. To Frigotto (2009), modern politics and educational management are characterized by social regression, uncertainty and political hegemony of commercial concepts. Feldfeber (2009), to quote another theorist, examines the internationalization of education and educational policies in Latin America through regional integration, openness, deregulation and privatization of the state processes, recognizing the central role of international agencies in the direction of reform policies by technical and financial assistance. These impositions, as Arelaro (2003) argues, are cause and consequence of perpetuating the public debt of developing countries.

However, many of these approaches do not seem to satisfactorily explain the internal logics of assimilation and agency that national states employ directly in front of the influential presence of what might be called the international community. This is because the distant, general and too engaged ways - "romantics", to use an expression of Ramos (1983) - by which some reflections interpret the importation relationships of foreign models for the national "culture", oversimplify a process (social, political, legal and administrative) that is extremely complex.

Precisely because of it, the formalism emerges as an alternative categorical possibility that helps to examine the implications of the Special Needs Education National Politics from the perspective of Inclusive Education - of the repealed Decree $n^{\circ} 6.571 / 2008$. This field of study was chosen as an objective possibility, since it involves national and regional processes of institutionalization, self-sustaining, transformation and redefinition of politics and laws that have historically been imported to (re) build the Brazilian education. The formalism, important in the national institutional context (Machado-da-Silva, Guarido Filho \& Nascimento, 2003), does not refer to any "bizarre feature" of national culture, but rather it is "a normal and regular fact, which reflects the overall strategy "of bureaucracy and Brazilian society (Ramos, 1983). Formalism refers to what Riggs (1964) described as the discrepancy between actual behavior and the prescribed standards that are supposed to regulate them and, therefore, constitutes a category of its own organizational and administrative theory (Ramos, 1983).

Given the previously stated, this article, circumscribed within the precepts of Organizational Theory, has as general objective: To understand, in the light of formalism, the impact that the repealed Decree $\mathrm{n}^{\circ}$ 6.571/2008 had in the management of inclusive education of Brazil, in particular, of the Rio Grande do Norte State Board of Education.

Thus, in addition to this introduction, this study contains the following topics: The Ministry of Education (MEC) and the State Board of Special Education (SEESP); Between Discourse and Practice: The Formalism in the Brazilian (Inclusive) Education; The methodological design; The current context of the Brazilian states inclusive education; The analysis of the Rio Grande do Norte State Board of Education and Culture case; and, Final Considerations.

\section{The Ministry of Education (MEC) and its State Board of Special Education (SEESP): From Special to Inclusive Education?}

In 1973, the first Board was created to exclusively manage the Brazilian special education under the name of National Center for Special Education (CENESP). Inclusive Education, nothing feasible at the time, was already a goal of CENESP: "If the education purposes are the same and if there is an underlying reality in the concept of exceptionality, there is no reason to be established options between the education of normal and exceptional: everyone has an equal access right to education" (Pires apud Silva, 2003).

Even before the creation of CENESP, in 1961, the National Education Bases and Guidelines Law (LDB, Law ${ }^{\circ}$ 4.024/61) grounded the educational services to people with disabilities, preferably within the general education system. However, due to scarce resources and lack of information about the population size of "exceptional" to be met was created the Law ${ }^{\circ} 5.692 / 71$ that amended the 1961 LDB, defining what special needs students should be referred to special classes and schools. It should be noted that the Brazilian education of pupils with special needs, historically, organized itself apart from the regular education with marked clinical approach; which resulted in an increasing segregation in specialized institutions, creating different education modalities and specialized institutions (Note 3).

With the Federal Constitution of 1988, the discourse of inclusive education comes back. Its 205, 206 and 207 articles establish the "equal access conditions", pointing out as obligation of the Brazilian State to meet special needs students "by preference in the regular school system". In 1990 the World Conference on Education for All is ratified and, in the same year, the Law $\mathrm{n}^{\circ} .8069 / 90$, in the Article 55, stipulates that parents must enroll their special education needs children in the regular education.

In 1994, the same year which celebrates the Salamanca Statement and Framework for Action on Special Needs 
Education (Note 4), the current State Board of Special Education (SEESP) publishes the National Policy on Special Education (PNEE), supporting that special needs student, with conditions to keep pace with other students, must have access to regular areas of teaching and learning. The law $\mathrm{n}^{\circ} 9.394 / 96$, regarding the LDB, in its article $\mathrm{n}^{\circ} 60$ regulates the inclusive education as a "preferred" alternative and defines the way in which its funding must be provided (Note 5). Decree $\mathrm{n}^{\circ} 3298$ (law $\mathrm{n}^{\mathrm{o}} 7.853 / 89$ ), 1999, defines the transversality of the special education - special education as a complement to regular education.

Also in 1999, the Convention of Guatemala was held, which deals with equal rights and freedom of pupils with special education needs; this convention was only promulgated by Brazil in 2001 (Decree $\mathrm{n}^{\circ}$ 3.956/2001). The National Educational Plan (PNE) was also released in 2001. With this plan, special education is definitely repositioned through the lens of inclusive education, assuming regular education to be responsible for students with special education needs and to enroll all the students under the motto "quality education for all".

With the PNE's release, the SEESP faced itself with the near absence of infrastructure, educational technologies, adequate materials and qualified teachers (PNE, 2001). In the following years the federal institutional mechanisms have not aimed changing the way of thinking about special education, since the inclusive education was already the elected option. To this end, subsequent decrees, resolutions and direct programs tried to overcome the encountered structural and functional limitations.

In 2002, the Resolution $\mathrm{CNE} / \mathrm{CP} \mathrm{n}^{\circ} 1$ decrees higher education institutions to be under the necessity to train educators to work accompanied by students with special educational needs. In 2003, MEC started implementing the "Inclusive Education" program in order "to support the transformation of the education systems in inclusive education systems, (...) the training of managers and educators $(\ldots)$, the provision of specialized educational care and to ensure accessibility "(MEC/SEESP, 2007). In 2004, emerges from the Decree $n^{\circ} 5.296$ the Accessible Brazil Program, of Ministry of Cities, which intends to create universal accessibility to common urban spaces and fund accessibility of all Brazilian public schools.

By 2006, the Convention on the Rights of Persons with Disabilities is adopted by the United Nations and reinforces that inclusive education system should be ensured by all signatory nations. Also in 2006 the teacher's training material "Educating for Diversity", used by MERCOSUR countries to train prepared teachers to respond to diverse learning styles and rhythms of their students (Note 6), was released. In 2007, MEC launches the Education Development Plan (PDE) which aims, among other goals, to overcome the difference between regular and special education (Note 7) - to force the implementation of PDE, was published Decree $\mathrm{n}^{\circ}$ 6.094/2007. Moreover in 2007, by adding to Decree $n^{\circ} 6.253 / 2007$, it's instituted the funding policy for inclusive education through double computation of special needs student registration in regular public education and in specialized education services.

Decree $\mathrm{n}^{\circ} 6.571 / 2008$, object of the present study, succeeds the Decrees $\mathrm{n}^{\circ} 6.094 / 2007$ and $6.253 / 2007$ to establish the treatment form, regulated one year later by CNE/CEB n ${ }^{\circ} 13 / 2009$ and by CNE/CEB n ${ }^{\circ} 4 / 2009$.

In order to implement the National Policy on Special Education in the Perspective of Inclusive Education, $\mathrm{CNE} / \mathrm{CEB} \mathrm{n}^{\circ}$ 13/2009 defines, in paragraph 1 of Article 1, the specialized education services as "the set of activities, resources, accessibility and pedagogical, institutionally organized, provided as a complement or supplement to the students formation in regular education". It also deals with the enrollment of special education needs pupils within the regular school space and with the Specialized School Treatment, enabling the delivery of this care in multifunction resource rooms in its own school, in another public school, or in specialized educational service center. Much controversy was created, at the time, by interpretation that MEC was suggesting the closure of special schools. As such, with Articles 1, 5, 8 and 11 of Resolution CNE/CEB 4/2009, the participation of special education institutions in the provision of services to special education needs students is granted. This resolution, however, does not go beyond that provided by Decree $\mathrm{n}^{\mathrm{o}}$ 6.571/2008.

Recently the Decree $n^{\circ} 6.571 / 2008$ was repealed by the Decree $n^{0} 7.611 / 11$ that accepts, for purposes of resources distribution, the computation of enrollment effected by institutions working exclusively with special needs students and that have agreements with the Executive Authority.

As showed in this topic, the development of legal-political regime indicates multiple attempts of ultimate restructuring of the Brazilian special education from the perspective of inclusive education. So, in less than ten years Brazil has passed from gradual inclusion - students with special education needs "preferably" enrolled in regular classes - to mandatory, and then back to gradual.

From the very perspective of formalism, as discussed in the next section, it is understood that an analysis of the formal (expressions of law) and informal aspects (formalistic behavior of social actors) can contribute to 
understanding the impact that the Decree $\mathrm{n}^{\circ}$ 6.571/2008 had in the management of inclusive education (Note 8).

\section{Between Discourse and Practice: The Formalism in the Brazilian (Inclusive) Education}

The formalism, identified by Riggs (1964) in Thailand and the Philippines, is a feature mostly found in "prismatic" societies - that are somewhere in-between traditional and modern. This "cultural trace", accordingly, can be understood as something ambiguous (Motta \& Caldas, 1997), that "corresponds to the degree of discrepancy between the prescriptive and the descriptive, between formal power and effective power, between the impression that is given to us by the constitution, laws, regulations, organizational setup and statistics, and the real facts and practices of government and society. The greater the discrepancy between the formal and the effective, the more formalistic the system" (Riggs, 1964).

According to Riggs (1964), the flaw in that social structure is in its own power structure, which is characterized by not being a formal authority strong enough to impose effective control over bureaucracy. The fact of prismatic societies often seek parameters in non-local practices, instead simply transplant foreign models, maintains the gap between structure and function - to a structure, in this sense, corresponds latent functions that concurrently take place with its manifest function (Riggs, 1964).

The formalism is studied for over one hundred years in Brazil (Ramos, 1983). As elucidated by Ramos (1983) for almost half a century, something is called formalistic when "does not faithfully represent reality". Therefore, from the work of Riggs (1964), we can say that the Brazilian organizational thinking, especially in the figure of Ramos (1983) (Note 9), built a certain understanding of formalism. Considering what has been thought by Ramos (1983) - because of the fact that formalism allows societies to absorb or reduce social conflicts, have upward mobility and articulate with the outside world - it's possible to affirm that formalism is about the development of a strategic look.

The formalism strategic point of view, designed and described from Brazil - a "mixed society" or "of intermediate" (Freitas, 1997) - allowed Ramos (1983) to assert the importance of this cultural trait in prismatic societies and refute the pathological and tautological character that for a long time has stereotyped the formalism. Since last century, until few decades ago, this practice had a negative connotative meaning; represented only what Holland (1995) called an index of our [alleged] inability to create spontaneously. However, it's not this "inconvenient" aspect of formalism (perpetuating the elites status quo and social inequalities), as stated by Castor (2000), which should be considered. Rather, the formalism is, as understood for this study, a strategy that articulates the external discourses to the practices and social, political and cultural contexts that are embedded in the Brazilian public organization; that is, as a way of reframing the foreign from "the standpoint of the national development" (Ramos, 1983).

It is important to mention the reading held by Castor (2000) on the strategic direction that Ramos (1983) granted to formalism, "referring to the period that did not exist, in our country, the specific conditions of self-articulation, which he stood in the colonial and in the beginnings of our independently social life, without assigning to formalism timeless and intrinsic merits". With regards pointed out by Castor (2000) - that contemporary defines formalism as the discrepancy between ostensible values, attitudes and real behaviors - this study, instead of trying to build a (self) sufficient concept, intended to describe how this practice is manifested, how it produces effects and how it relates with other things we already know.

However, this is not to say that the study fails to recognize that from independence the formalism becomes a natural attribute of the country (Machado-da-Silva; et al., 2003). So, perhaps it is possible to understand how the formalism, strategic during the colonial period, can still be considered an important way of looking at organizational relationships today; contributing to collapse the "romantic" visions about the state bureaucracy. As Herzfeld (1992) suggested, "rejecting the hateful formalism of bureaucracy is itself a conventional, formal act, and identifies areas of tensions between official norms and more localized social values".

For Machado-da-Silva et al. (2003), historically the state preceded the Brazilian society in an endless process of foreign practices transplantation. However, "the constitution of society does not only happen in its relationship with the world, but also by the interaction between their constituents" (Machado-da-Silva et al., 2003). As previously noted, for more than half a century our society has been discussing possibilities for working the special education in the inclusive education perspective: "It is easier to adopt by decree or by law a organization formal structure (...) than institutionalize the corresponding social behavior" (Riggs, 1968). In this case, the formalism allows us to question the apparent stability and uniformity of institutional practices and discourses of the national public administration. After all, as stated by Machado-da-Silva et al. (1999), "for more than isomorphic forces push towards homogenization of the structure and organizational action within a niche, there will always be diversity due to the particularities of interpretive schemes". Specifically for this study, it is 
to see how the own practices that preach for inclusion can be formalistic, allowing, instead, the emergence of different senses to this rhetoric:

What bureaucracies do is, in this sense, not appreciably different from what all attempts to consolidate power entail. They batten on to an existing cultural vocabulary. People - bureaucrats and clients alike - then make their perspective accommodations to this new order. In so doing, they are not necessarily accepting it. They may be doing just the opposite, by playing the letter of national law against its intentions (Herzfeld, 1992) (Note 10).

Finally, it is important to note the fact that the formalism is taken here as a perspective of analysis of inclusive public policies (Note 11). Therefore, it is not a closed concept, but a way to set before the organizational studies. This, however, implies recognizing that:

There is no safe haven, where we can anchor our analytical perspective, and, from there, know the reality. At each stop we can badly tie up to the surface. And then build a new way of seeing the world and our relationship with it, neither better nor worse than others, no more correct or more wrong than others (Veiga-Neto \& Wortmann, 2002).

Thus, this analysis focuses on understanding how the Brazilian inclusive education has been managed from the Decree $n^{\circ}$ 6.571/2008 (AQUI PODERIAMOS COLOCAR 2 OPÇÕES: while the Decree $n^{\circ}$ 6.571/2008 lasted OU from the repealed Decree $\mathrm{n}^{\circ} 6.571 / 2008$. O QUE ACHA MELHOR?), considering the formalism perspective of analysis. To investigate this phenomenon theoretical and empirically, we adopted the following methodological design, presented below.

\section{Methodology}

Once stated the research problem, from "where we look and think the same reality" (Corazza, 2002), the study methodological practices are discussed (Creswell, 2007). The overall goal is to understand the impact that the repealed Decree $\mathrm{n}^{\circ} 6.571 / 2008$ had in the Brazilian management of inclusive education, in particular, at the Rio Grande do Norte State Board of Education.

The research is predominantly qualitative, with a quantitative and descriptive dimension. Adopting this approach requires entering the world of the organizational actors and seeking their perspectives, meanings and action theories. As to the method, it is a multi method approach, conducted in two stages.

In the first stage, a research survey was held - a census investigation with the population represented by the 27 Brazilian State Boards of Education - addressing the relationship between formalism and Inclusive Education through: (1 ) secondary data: analysis of web pages, reports and official documents of the 27 State Boards of Education, and (2) primary data: semi-structured interview via telephone calls and e-mails with a representative from each State Board of Education representing the official discourse of their respective Department of Special Education. Among the 27 Brazilian State Boards of Education - Departments of Special Education - contacted, were obtained 14 responses via email and telephone alike.

From the responses obtained and the analyzed documents, whose data were processed through content analysis, we tried to check the reviews and trends of the group as a whole (Saunders et al., 2000). This research does not directly provide reflection on the existence, or not, of variation on individual perceptions. Considering the above stated, the choice of a single representative from each Department of Special Education was sufficient since the respondents affirm to have the voice to represent the official discourse of their respective Department (Note 12). Interview data were recorded, transcribed and coded in order to preserve the anonymity of respondents.

In the second step, a single case study was realized at the Rio Grande do Norte State Board of Education (SEC/RN), more specifically at its Department of Special Education (SUESP). The selection criteria was the accessibility and availability of the organizations interviewed. Data collected from the first step allowed to observe that the SEC/RN works towards the inclusive education perspective even before it was determinate by MEC, thus representing, for Riggs (1964), a constitutional formalism - that is characteristic of any political dimension. During talks with the representatives of the SEC / RN, a school was pointed out as a problem and, it was then decided, to include this institution in the research scope.

With this sectional study, conducted ex post facto, is expected to reflect on: (1) the Brazilian special education needs treatment on the public agenda of the various State Boards of Education in its relation to the repealed Decree $n^{0} 6.571 / 2008$; and (2) the local meanings of the (apparently) consonant practice with the repealed Decree $n^{\circ} 6.571 / 2008$ undertaken by the Rio Grande do Norte State Board of Education in its relationship with one of its schools.

The analysis level is inter-organizational. It involves macro and micro analysis. The used analysis unit is the 
impact of the repealed Decree ${ }^{0} 6.571 / 2008$ in the Brazilian inclusive education management, especially, in Rio Grande do Norte State Board of Education. The observation unit was composed by: (1) 14 Brazilian State Boards of Education representatives; (2) actors of the Rio Grande do Norte State Board of Education Department of Special Education (SUESP); and (3) the director of one of the Rio Grande do Norte State Board of Education schools. Data was collected during the second half of 2010 and analyzed until April 2011. The Decree $\mathrm{n}^{\circ}$ 6.571/2008 was repealed in November 2011.

The data obtained from sector documentary data collection (laws, decrees, orders, guidelines, etc.), organizations visited, and the interviews, were triangulated to ensure validity of the study and obtain new perspectives of knowledge (Vergara, 2005).

\section{The Brazilian States Inclusive Education Situation during the Birth and Death of the Decree $n^{\circ}$ $6.571 / 2008$}

The interviews surveyed with all 14 State Boards of Education in the first step allowed observing that the common speech of all representatives/actors was to emphasize the commitment with inclusion policies - what could suggest that the public organization of special education goes with the inclusive education perspective as proposed by the MEC at the time. This position, however, may have very different implications in the public policies organization depending on the translation given by each region. An example can be the representative number of secretaries who claim to have its own policy for inclusive education - between the ten who voted on this issue, six (60\%) reported as working with own "plans", "guidelines" or "orientations".

Clearly, it is not say that the existence of parallel policies proposed by the MEC implies in a formalistic practice by these State Boards of Education. However, shows signs of how MEC programs have been located and translated into regional realities: Yes, we work from the inclusive education perspective, in accordance with MEC guidelines. We respect the differences, we believe in people with special education needs, in the rights ruled by existing legislation and the projects developed by MEC that has helped a lot the work in this area. (...) However, there are special schools with all the required credits which they deserve, because they were created long ago and have always supported people with disabilities, the need is a new look that should go to these schools. It should be noted where inclusive education is not reaching students with disabilities, for those who are already at an advanced age and don't have a different and enjoyable activity to participate. I believe there will always be the special school, because students with multiple disabilities cannot follow the regular school curriculum. Neither the common schools have clinical treatments that special schools offer (State Board of Education number 07).

While it is possible to observe how the federal public policy adapts to the local context, it is also feasible to say that these contexts are modified in front of national requirements. This was verified in the interviews as among eight State Boards of Education, 50\% work the special education from the inclusive education perspective "even before the new policy of MEC", while 50\% started working only after 2007. It is about a not linear localization process

In this research, it became especially evident with the disparity of speeches on: the restructuring of special schools into specialized educational service centers, which should be located within or in partnership with common schools; and the inclusion of all students in the regular school system "whenever possible", like proposed by the repealed Decree $\mathrm{n}^{\circ}$ 6.571/2008. For the vast majority of Brazilian states -9 out of twelve (75\%) - retention and maintenance of special classrooms and schools indicate administrative, politic and education process conformations that differs from that recently devised by MEC. This fact can be illustrated by the following actor's talk: We have agreements with Nonprofit Organizations and teachers. In these Nonprofit Organizations they have the special rooms (...). For this year 2010 we are still extending the covenants, because as I said, it is a hierarchical issue, requires bidding and everything, and even the Nonprofit Organizations structure (State Board of Education number 3).

This mismatch between national policy and the state realities can be observed by noticing that, of nine State Boards of Education that have special modalities of teaching, three (33\%) have a term to include all students in regular study, and six (66 \%) do not. To the State Board of Education number 06, to set a deadline means facing great resistance from parents, but, mainly, means to conform the organizational discourse to fund special education in the state: If you have special room there is no money. This impasse was only resolved in part, when the Articles 1, 5, 8 and 11 of Resolution CNE / CEB 4/2009, started to forecast the participation of special education institutions in the provision of services to students with special education needs; a federal policy adjustment that was influenced by local and regional contexts.

Therefore, the external influences, indicating the closure of special schools, suggested to Brazil to change its 
federal unit's education system structure. In this restructuring, as indicated in the Salamanca Statement (1994), special schools should be "exceptions", and when necessary should be located "in inclusive schools", providing "the most suitable education for a relatively small number of children with deficiencies which cannot be adequately treated in regular classrooms or schools". Until the Resolution CNE / CEB 4 / 2009, MEC tried to contain the State Boards of Education investments in special schools and convening, as evidenced in this speech: At this stage we are justifying the special schools structure in the state. And that's a fight, because what has been done so far was with our own resources. To give you an idea we submitted to MEC a teacher training action: 'teacher training in special education'. It was not approved because it had to be for basic education teachers, that are suppose to mediate special education needs students in regular classrooms. The MEC does not want the difference anymore (State Board of Education number 06).

This coercive dimension of the process has gone through numerous phases of renegotiation between MEC and the State Boards of Education. The 2009 Resolution is the result of regional, local, historic and constitutive pressures of Brazilian society, unveiling the complex process of Brazilian constitution, as can be noted: There is no indication to end with the special schools in our state. Also because special institutions, such as APAE [Association of Parents and Friends of Exceptional], for example, offer other types of goods and services, such as occupational therapy (State Board of Education number 10). Our State Board of Education guarantees the access right and permanence to specialized educational services for students with intellectual disabilities who need pervasive support, enabling the celebration of agreements with institutions that hold free educational service, in special Education, disciplined in specific legislation: Decree $n^{\circ} 54887$ of October 7, 2009, Resolution $S E N^{\circ}$ 72, October 9, 2009 and Decree $N^{\circ} 40722$ of March 20, 1996. Currently there are a total of 299 students covered by covenants. (...) The decrease of special classes, the reorganization of the work with APAE, the funding of Special Education for Work and gradual exclusion of students with more than 30 years of the agreements listfor routing to more adequate activities with their age - are goals for strengthening the public services and consequently integration and respect for the deficient student (State Board of Education number 13).

Paradoxically, even though all the State Boards of Education have assumed to work special education on the inclusive education perspective, this position involves various concepts and actions. This can be seen in different and contradictory meanings that "inclusive education" assumes in the discourse of the State Boards of Education. Grouped below are, into five major groups, the responses of 14 representatives who manifest toward the question: To your State Board of Education, what does inclusive education means?

(a) Politic conception: integrate / include "all" or "most" in the regular room; perform a "progressive", "responsible" or "gradual" integration / inclusion; and recognize that there are students who "cannot" be integrated / included;

(b) Pedagogical and financial investments: to have interpreters in the classroom, "whenever necessary"; to have resources and equipment; to continuously promote special education teachers improvement; to have a monitor to accompany students with special education needs and work cooperatively with the teacher; to accomplish itinerary formations throughout the state; to have the common schools structure capable to receive special needs students;

(c) Regional system restructuration: transform schools into educational centers of specialized services; finish with special schools and also maintain those; renew agreements with Nonprofit Organizations and do not have more convening schools; deploy the specialized educational services in schools; work with special students included in regular room but also in special rooms, convening schools and specialized educational centers; receive MEC formation; receive MEC resources for training and to universalize the access; have a technical team, whether in common or special school, composed by occupational therapists, social workers, speech therapists and other professionals; establish specific maximum number of students per class; have itinerant teachers serving schools; deal with municipalities;

(d) Ideological conception: to support the common school; to support special education professionals; respect the abilities of all students, avoiding comparisons between "special" and "normal"; transform the school spaces in inclusive and crash, at the same time, in a "oiled" structure; to create a legitimate structure for the parents; deal with local interests conflict; respect the differences; believe in the special needs students; to sensitize the regular school;

(e) Political Alignment: ensure the rights of Brazilian law; follow the MEC policies and guidelines; have its own policy; follow the tendency because not only our State Board of Education, but the whole Brazil is walking to this; it is a worldwide movement (Note 13).

As possible results of working special education in the inclusive education perspective, responses from eight 
states were obtained: Better and more frequent teacher education appeared in $62 \%$ of responses; and, greater number of students included in $37.5 \%$ of responses. Still, among the results, it is noteworthy more resources, awareness and educational advice, with $25 \%$ and broader vision, more respect, better adaptation architecture, with $12.5 \%$. Only one state has recognized that there are also bad results related to internal and external conflicts to the schools that such policies would be promoting, representing $12.5 \%$.

It is believed that the present session of the research gives evidence that the repealed Decree $\mathrm{n}^{\circ} 6.571 / 2008$, analyzed from the perspective of formalism, based on its formal aspects (expressions of law) and informal (formalistic behavior of social actors), was translated and interpreted differently in each context of organizational practice. The objective of the description is to provide understanding of the impact that this Decree had in the management of inclusive education and to confirm that "however isomorphic forces that push towards homogenization of the organizational structure and action within a niche, there will always be diversity due to the specifics of interpretive schemes" (Machado-da-Silva et al., 1999: 03). Each educational system has its own network and different actors working, moving and creating controversies. As the discussed 2009 Resolution was the result of regional, local, historic and constitutive pressures of Brazilian society, the Decree $\mathrm{n}^{\circ} 7.611 / 2011$, which repealed the Decree $\mathrm{n}^{\circ} 6.571 / 2008$, also is associated with those pressures.

In the following session an analysis of the Rio Grande do Norte State Board of Education inclusive education management is reviewed. A State Board that touts the inclusion perspective and that has been working with special needs students in regular spaces "even before the MEC". An equally formalistic representation that allows the emergence of different senses to this discourse.

\section{Rio Grande do Norte State Board of Education: Dissidence or Compliance?}

As observed in the previous session, the Brazilian educational system presents a wide variety of local positions on the institutional perspective of inclusive education. This is because, according to the (official) statement of its representatives, each State Board of Education represented the legal devices provided by the federal government from the regional administrative and political contexts, adapting their speech and actions to the formalities that were imposed by MEC at the time.

In order to overcome this formal adequacy and contribute to a more effective understanding of the impact that the Decree $\mathrm{N}^{\circ}$ 6.571/2008 had in the Brazilian public education management, it was carry out a case study in one of the State Boards of Education who stood ideologically favorable and administratively aligned with the paradigm of special needs pupils total inclusion in mainstream education. Finally, this stage of the study opted to focus on the Rio Grande do Norte State Board of Education; in specific approach SUESP and its inter-organizational relations with one of the (regular) schools where inclusion is conducted.

The initial contact with the State Board of Education was established by telephone. After coursing the extensions of some departments of its School Development Coordinator (CODESA), responsible for organizing the basic education in the state of Rio Grande do Norte, the call finally stopped at SUESP. As reported, this was "the hardest working area with the development and implementation of inclusion policies" - reproducing a concept still very present in public institutions which localizes the inclusion perspective almost solely within the policies undertaken by special education, as if it was separated from the rest of basic education. So, a representative of the SUESP pedagogical team was nominated to answer the interview.

The conversation was brief this time; the issues involved only the Rio Grande do Norte State Board of Education (official) position on the Decree $\mathrm{n}^{\circ}$ 6.571/2008 guidelines for inclusive education: We have been working in this view for some time. I can even say that we precede the new policy, but we are still moving in this way, this direction, really aiming that [inclusive education] actually happens in all schools (...). We began in 1990, now we are making small adjustments to our policy (...), we have no special schools in Rio Grande do Norte, and it has only Specialized Service Centers. But a Center is not a school (...); the current challenge is to break down some barriers that still remain - of attitude, accessibility (Interviewee 01).

To the actors who were interviewed, the 2008 special education "new politics" - inclusive education perspective - seems to legitimize the work already done by SUESP since the early nineties. After comparing this information with data provided by other State Boards of Education surveyed, it was decided to deepen the analysis in this context. Especially because the Rio Grande do Norte State Board of Education official discourse was suggesting being away from formalism, allowing verifying the extent to which this organization could act in line with the national rules and regulations at the time.

Thus, another interview was scheduled; a personal one at this time, at the Rio Grande do Norte State Board of Education Administrative Center, in Natal, where SUESP runs. An educator who works with "itinerant projects" 
and "multifunctional resource rooms" (Note 14) was designed to answer the questions. As closed questions were not developed, the meeting soon turned into a casual conversation, in which the interviewee was keen to tell his own career in special education to explain the main changes in the organization of the education state system with the advent of proposals for educational inclusion: I work at the pedagogical sector for over 30 years with early childhood education - it was called nurseries. At that time they had children with hearing, visual and mental deficiencies and I went to coordinate this work with our teachers, from SUESP. We made up what the family did not offer; such care that the mother did not give. We also had those with intellectual disabilities, but rather than progression they were segregated (...). The special rooms were just like this, from 1976 to 1984. (...) In 1985 began the alert to integrate in our State - in a room with normal students, 3 or 4 students with special education needs would be put. They were what we call objects. They were there just to say we were integrating. It was not inclusion. It was to be in, to live with. (..) At that time we began to realize it was a prejudice, a large discrimination, they were discriminated in the break time, at parties, in any activity - even in the lunch line they were rejected. Then came the MEC, in 1985, and started the alert (...), in the 90's, then, the bomb exploded, had to be total inclusion! It was uproar (Interviewee 02).

From this point on the interviewee began to describe the main consequences that the inclusion paradigm, started back in the 1990s, produced on the public (special) education management in Rio Grande do Norte: The teachers revolt led to the need of training (...), there was a resistance by the schools for these students to remain segregated and integrated. There was resistance. There was not, there is still much resistance. But it has been decreasing, mainly because MEC says that to be in the multifunction rooms the staff has to be trained. So I say that the mark of this whole process was indeed 2003. The inclusion rocked since 1990. In 2000 [in Rio Grande do Norte] almost no more special schools existed - just some hidden on the countryside. I got one in 2000 that was like this (...), the school persisted to keep a special room, and we broke off. There was much confusion. (...) But it was after 2003 that everything really began with the after/before school rooms. Today there is always on school days the itinerant teacher. We have worked in training, sensitizing teachers. So I think everything is going well, especially after the multifunctional resources room (Interviewee 02).

According to this description offered by the interviewee, the Rio Grande do Norte special education is presented from a movement of four decades - the education administration transited from an assistance model to an integrationist conception and, later, inclusive one. This process, since 2003, is legitimized by MEC national policies, with the financing of multifunctional resource rooms and itinerant projects developed by the state in initial and continued training of special education professionals - at least up to the advent of the Decree 7.611/2011, which effective changes are still being studied.

However, this positive evaluation of the inclusive educational policies made by representatives of the Rio Grande do Norte State Board of Education was very different from the one made by the director of a school in Natal. This school was selected since interviewee 02 highlighted this organization as a dissonant voice in the state - "a problematic school". When asked about the work performed by SUESP in promoting the current inclusive education policy, the director revealed: The inclusion is implemented in schools. The staff will receive the students, the schools are open, but nobody has any formal training. It is not about wrestling, but I'm always in conflict with SUESP for many reasons. They talk, theorize, but the practice of education falls short. And we are looking at one of the few schools that have these multifunction resource rooms and receive all special needs students. But is the teacher prepared to receive students with special education needs? No, he is not prepared. (...) I was a teacher in the classroom, dealing with special students within the process of the students considered normal. I had some experience because I am graduated in sociology, I have worked at APAE, and I have experience and still had tremendously difficulty. But teachers who never had contact with special education needs pupils and now have an obligation to get these students in the classroom, how do they do? SUESP itself does not worry about it. For example, how one will deal with deaf if he does not know sign language?" (Interviewee 03).

Thus, the director criticized the SUESP work, especially in what regards its main flags: The SUESP only deals with the multifunctional room. But it alone does not support the classroom teachers. The SUESP visits are only for multifunctional rooms, they do not support teachers in the classroom. Then I do not believe this process work. (...) So I say that the SUESP discourse is beautiful, but in practice it is different. They want us to accept students, including these students in the classroom and teachers are unprepared. We connect requesting training and they do not even accept that the classroom teacher make a course. (...) So what is the work of itinerant project? What does the itinerant do? They now consider that the program is running and working in a 100\%. If there is the itinerary program I think it has to be improved a lot (Interviewee 03).

Finally, the director ended her speech questioning SUESP own position and pointing to what might be called a 
formalistic practice in the Rio Grande do Norte education public management: Not all special students who are here want to go to regular school. So I think the special school, or whatever you call it, is a space that cannot just stop existing. It has equipment, qualified teachers in this area (...), in the normal school the only specialized teachers are the ones of the multifunctional room - which is the space of the reinforcement, the special place. I wonder if the folks at SUESP really believe that what they do is inclusion or is only to say that the state is inclusive (Interviewee 03).

The gap between the SUESP representatives discourse and of the school director that is part of this education regional system is evident, albeit limited by the performance of a unique director. It is not up for this study to determine the legitimacy or accuracy of these reports, because it is not intended to oppose even more of those positions; unlike, this only sought to record the presence of formalistic aspects in the process of public education reorganization that are being driven by a different portion of agencies in special education.

\section{Discussion}

In addressing the formalism in the context of inclusive education, it was meant to examine together some of the processes that position all Brazilian education system in the same direction (official) during the birth and death of the Decree $\mathrm{n}^{\mathrm{o}} 6.571 / 2008$, creating strategic associations and arrangements that mobilize local transformations from external speeches - being national or international. Accordingly, it was noticed that the formalistic practices emerges in educational institutions as redefining possibilities to face the requirements of regulatory organizations. To suit local - or even national - needs and demands. Thereby contributes to capture the influence of the strategic uses of the legal and state policies that the public administration performs.

From a theoretical point of view, the expectation is to have called attention to the formalism presence in public education, especially in special education. As already noted by Machado-da-Silva et al. (2003), it is about realizing that such practices "are not characterized only by the frequent imposition of rules - when they are not grounded in the customs - but also as a cultural trace that integrates the behavior of social actors". Given the constant changes in legislation and policy guidance of various Brazilian education instances, the (coercive) pressure impose accelerated dynamics of (discursive and practice) adaptation that are shared by actors and organizations. It is noteworthy that the study enabled to verify the existence of an unstable legal framework with the equivocal positions of state official.

Therefore, when analyzing the impact that the Decree $\mathrm{N}^{\circ} 6.571 / 2008$ had on the Brazilian public education organization, it is concluded that the practice allows formalistic organizational studies to examine the effectiveness of the policies of official knowledge (APPLE, 1997) and its other forms of narrating not only special education, but the very plurality of logical and social experiences.

The methodological design brings some limitations to this work, as well as the difficulties to access financial and physical resources for inquiring all states. It is also necessary to point out the limitation of the number of interviews conducted in the second stage of the research. However, it is understood that this research had a short time to be developed. New studies, based on the results achieved, may be made to enlarge the understanding of a phenomenon that involves macro and micro levels of analysis.

As suggestions for future researches it is recommended a deepening understand of the special education needs context of the pupils and its history in Brazil; to conduct new case studies, single or multiple, taking into account the advent of the Decree $\mathrm{n}^{\circ} 7.611 / 2011$, as there is little consensus on the text changes clarity relative to the Decree $\mathrm{n}^{\mathrm{o}} 6.571 / 2008$; and the inclusion of other actors and intervenient categories such as formalism.

\section{References}

Apple, M. W. (1997). Conhecimento oficial: A educação democrática numa era conservadora. Rio de Janeiro: Vozes.

Associação de Pais e Amigos dos Excepcionais - APAE Brasil. (2011). Histórico da APAE no Brasil. Retrieved from http://www.apaebrasil.org.br/artigo.phtml? $\mathrm{a}=2$

Azevedo, A., \& Albernaz, R. O. (2010). A Redução Sociológica em status nascendi: Os estudos literários de Guerreiro Ramos publicados na revista Cultura Política. Revista Organizações \& Sociedade, 17(52), 47-68.

Berg, B. L. (2001). Qualitative research methods for the Social Sciences. Boston: Allyn and Bacon.

Boava, D. L. T., Macedo, F. M. F., \& Ichikawa, E. Y. (2010). Guerreiro Ramos e a Fenomenologia: Redução, mundo e existencialismo. Revista Organizações \& Sociedade, 17(52), 69-83.

Cooper, D. R., \& Schindler, P. S. (2003). Métodos de pesquisa em administração. Porto Alegre: Bookman. 
Corazza, S. M. (2002). Labirintos da pesquisa, diante dos ferrolhos. In M. V. Costa (Ed.), Caminhos investigativos, novos olhares na pesquisa em educação. Rio de Janeiro: DP\&A.

Creswell, J. W. (2003). Research design: Qualitative, quantitative and mixed methods approaches. London: Sage.

Creswell, J. W. (2007). Projeto de pesquisa: Métodos qualitativos, quantitativo e misto. Porto Alegre: Editora Artmed.

Eisenhardt, K. M. (1989). Building theories from case study research. The Academy of Management Review, 14(4), 532. http://dx.doi.org/10.2307/258557

Feldfeber, M. (2009). Internacionalização da educação, tratados de livre comércio e políticas educativas na América Latina. In E. Ferreira, \& D.A. Oliveira (Eds.), Crise da escola e políticas educativas. Belo Horizonte: Autêntica.

Ferreira, E., \& Oliveira, D. A. (2009). Crise da escola e políticas educativas. Belo Horizonte: Autêntica.

Freitas, A. B. (1997). Traços brasileiros para uma análise organizacional. In F. P. Motta, \& M. P. Caldas (Eds.), Cultura organizacional e cultura brasileira. São Paulo: Atlas.

Frigotto, G. (2009). Política e gestão educacional na contemporaneidade. In E. Ferreira, \& D.A. Oliveira (Eds.), Crise da escola e politicas educativas. Belo Horizonte: Autêntica.

Herzfeld, M. (1992). The social production of indifference: Exploring the symbolic roots of western bureaucracy. Chicago: The University of Chicago Press.

Machado-da-Silva, C. L., Guarido Filho, E. R., Nascimento, M. R., \& Oliveira, P. T. (2003). Institucionalização da mudança na sociedade brasileira: O papel do formalismo. In M. M. F. Vieira, \& C. A. Carvalho (Eds.), Organizações, instituições e poder no Brasil. Rio de Janeiro: Editora FGV.

Ministério da Educação. (1971). Lei de Diretrizes e Bases da Educação Nacional. LDB 5.692. Estabelece as diretrizes e bases da educação brasileira. Seção 1:27,839. Brazil, Brazilian government.

Ministério da Educação. (1988). Constituição da República Federativa do Brasil. Brazil, Brazilian government.

Ministério da Educação. (1994). Declaração de Salamanca e linha de ação sobre necessidades educativas especiais. Brazil, Brazilian government.

Ministério da Educação. (1998). Declaração Mundial sobre Educação para Todos. Brazil, Brazilian government.

Ministério da Educação. (2001). Plano Nacional de Educação. Lei nº 10.172. Brazil, Brazilian government.

Ministério da Educação. (2007). Plano de Desenvolvimento da Educação: Razões, princípios e programas. Brazil, Brazilian government.

Ministério da Educação. (2010). Inclusão responsável e gradativa no Paraná contraria posição do MEC. Retrieved from www.gazetadopovo.com.br

Oliveira, D. A. (2009). Política Educativa, crise da escola e promoção de justiça social. In E. Ferreira, \& D. A. Oliveira (Eds.), Crise da escola e políticas educativas. Belo Horizonte: Autêntica.

Pinheiro, H. L. (2003). As políticas públicas e as pessoas portadoras de deficiência. In S. Silva, \& M. Vizin (Eds.), Políticas públicas: Educação, tecnologias e pessoas com deficiências. Campinas: Mercado das Letras.

Prestes Motta, F. C., \& CALDA, M. P. (1997). Cultura organizacional e cultura brasileira. São Paulo: Atlas.

Ramos, A. G. (1983). Administração e contexto brasileiro: Esboço de uma teoria geral da administração. Rio de Janeiro: Editora FGV.

Riggs, F. W. (1964). A ecologia da administração pública. Rio de Janeiro: Editora FGV.

Saunders, M. N. K., Thornhill, A., \& Lewis, P. (2000). Research methods for business students. Harlow: Prentice Hall.

SEESP. (2007). Política nacional de educação especial na perspectiva da educação inclusiva. Brasília: MEC.

Silva, S. (2003). A política educacional brasileira e as pessoas com deficiencias: Como difundir o discurso de uma política pública de direitos e praticar a privatização. In S. Silva, \& M. Vizin (Eds.), Políticas públicas: Educação, tecnologias e pessoas com deficiências. Campinas: Mercado das Letras.

Veiga-Neto, A., \& Wortmann, M. L. C. (2002). Introdução. In M. V. Costa (Ed.), Caminhos investigativos: Novos olhares na pesquisa em educação. Rio de Janeiro: DP\&A. 
Vergara, S. C. (2005). Métodos de pesquisa em administração. São Paulo: Atlas.

\section{Notes}

Note 1. Authors such as Ferreira and Oliveira (2009) and Pinheiro (2003) argue that, although the contemporary political and educational rhetoric present the inclusive education as new, inclusive policies have been the subject of intense debate in public education at least since the early 70 s.

Note 2. Guiding principles of this Decree are: (1) World Conference on Education for All, Jomtien, Thailand (1990); (2) The Salamanca Statement and Framework for Action on Special Needs Education, Spain (1994); (3) The Convention of Guatemala (1999); (4) The World Education Forum, Dakar, Senegal (2000); (5) Convention on the Rights of Persons with Disabilities (2006), approved by the UN. Regarding the member states of Mercosur, as is the case of Brazil, it should be also important to attempt for the existence of the program (5) Educating for Diversity (2003), on continuous training of managers and teachers, that was based on the teacher's training material Special Needs in the Classroom, from UNESCO.

Note 3. "In Brazil, the care for people with disabilities began in the days of Empire, with the creation of two institutions: the Blind Boys Imperial Institute, in 1854, current Benjamin Constant Institute - IBC, and the Deaf and Dumb Institute in 1857, now called the Deaf National Institute of Education - INES, both in Rio de Janeiro. At the beginning of the twentieth century it was created the Pestalozzi Institute (1926), an institution specialized in mental health issues for people with special needs; in 1954, the first Parents and Friends of Exceptional Children Association - APAE, was founded; and, in 1945, it is created the first specialized educational services to people with giftedness at Pestalozzi Society, by Helena Antipoff" (MEC/SEESP, 2007).

Note 4. The Salamanca Statement (1994), which influenced public policies from the inclusion perspective, is a recurring subject of studies around the world and the target of strong criticism for its economic vision: "the vision of a disabled child as a being that must be prepared for the assumption of functions in the capitalist structure is present, stressing the economic utility of education and the economic benefits for the child and their social environment. The paradigm that is evident (...) appears to be economic development and not the human one as it is not pointed out the possibilities of education for the expansion of the child languages and for the full childhood experience" (Oliveira \& Pinto, 2004: 3).

Note 5. In Law $n^{\circ}$ 9.394/96 stands out the following articles: Article 59. Education systems will ensure special needs students with: I - curricula, methods, techniques, educational resources and specific organization to attend their needs; II - special termination for those who cannot reach the required level for primary education completion, because of their disabilities, and acceleration to complete the curriculum for the gifted in less time. Article 24, section V: possibility of progress in courses and series by learning evaluation. Article 37: (...) appropriate educational opportunities, considering the characteristics of students, their interests, living conditions and work, by courses and exams.

Note 6. The teacher's training material Special Needs in the Classroom of UNESCO fundaments the program Education for Diversity. Research on the creation of this material began in 1998 with a work team that carried out field research in Canada, Chile, Jordan, Kenya, Malta, Spain and Zimbabwe. The coordinator team of the Education for Diversity in the MERCOSUR countries does not claim that this is purely an "importation", but a result of the search for knowledge with adjustment and use strategy of it in accordance with local realities. This project began in 2001 with the initial sample of twenty-five schools, being five schools per country, located in the same region, representing different realities: rural, suburbs, urban and intercultural.

Note 7. In what refers to inclusive education, reinforces its need and sets out ways to work the teacher's training, the deployment of multifunction capabilities rooms, the school buildings architectural accessibility and the access and retention of people with special needs in higher education (MEC/SEESP, 2007).

Note 8. As evidenced by Herzfeld (1992: 179), in discussing with Durkheim, "it is easier to conceive of a reified society worshipping itself when one can identify the agents of that reification, and when one can follow its reproduction through endless petty reclassifications, than when the system of collective representations is presented as given and unchanging".

Note 9. Azevedo and Albernaz (2010) discuss the "sociological reduction" of Ramos $(1965,1989)$, which sought, through received senses, the foundation of theoretical constructs in social practice in an unprecedented era of development and industrialization in the Brazilian history, which led our society to import models and practices elsewhere. To Boava, Macedo and Ichikawa (2010: 75), Ramos (1989) transplanted the ideas around the "phenomenological method" of Husserl to the field of sociology seeking to critically assimilate the foreign literature, abstracting the essence of the manufactured truth, since that "all foreign scientific production is, in 
principle, subsidiary" (Ramos, 1983:120), to rethink the uniqueness of the Brazilian society, working in a construction free of shadows, local and critical.

Note 10. Herzfeld (1992) write that paragraph as the conclusion of an analysis conducted by him to the work of Brogger (1989). Brogger apud Herzfeld (1992) conducts an ethnographic account of Nazareth, a small Portuguese fishing village that is, for the author, on the brink of radical change. Herzfeld (1992: 57) does not question the "likelihood or magnitude of that change, but where it will be located", since he does not agree with Brogger (1989) "that predicts that the traditional values and beliefs, having served some useful adaptive purposes during the earliest phases of state-directed bureaucratic and industrial intrusion", will soon disappear: "he may be right about some specific ways. But others are likely to persist, or as external symbolic forms, then as structures of thought that continue to provide an organizational scheme for people trying to come to terms with change, and that will permeate the reactions of the bureaucrats themselves" (HERZFELD, 1992).

Note 11. Flexibility rises of formalism and adaptability and creativity are faces of flexibility (PRATES; BARROS, 1997).

Note 12. The Idea of limiting the research to the "official discourses" - to the international, to the Brazilian, to the Brazilian State Boards of Education and to the Rio Grande do Norte State Board of Education - is due to contrast, through a formalism perspective, how these different official discourses treat meanings as absolute and unchanging alike. Providing this way a discursive model for the essentialism that is sometimes of a "international character", others of a "national character" (Herzfeld, 1992) or of a "local character", as we shall see also through the official discourse of a school located in Rio Grande do Norte representing the practice of a school with regular and special needs students.

Note 13. Often, as for State Board of Education number 11, the MEC seems to be not only the main north, but the only one.

Note 14. The Salamanca Statement (1994) suggests that only countries with no history with special schools should focus on the unique development of inclusive schools and specialized services. Thus, the Salamanca Statement (1994) recognizes that the situation of special needs education varies from country to country. However, it points a best way: "investments in existing special schools should be canalized to provide professional support to common schools in order to meet the special educational needs" (Salamanca Statement, 1994). 